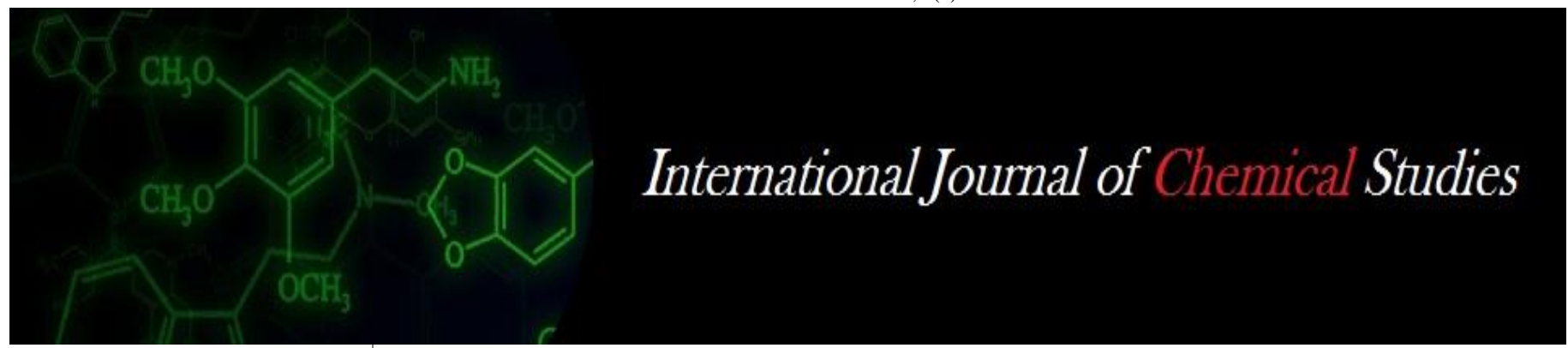

P-ISSN: 2349-8528

E-ISSN: 2321-4902

IJCS 2020; 8(1): 1609-1612

(C) 2020 IJCS

Received: 16-11-2019

Accepted: 18-12-2019

\section{VU Raut}

Horticulture Section, College of Agriculture, Amravati Road,

Nagpur, Maharashtra, India

\section{Pooja Baghele}

Horticulture Section, College of

Agriculture, Amravati Road,

Nagpur, Maharashtra, India

Neha Chopde

Horticulture Section, College of Agriculture, Amravati Road,

Nagpur, Maharashtra, India

\section{Seema Thakre}

Horticulture Section, College of Agriculture, Amravati Road,

Nagpur, Maharashtra, India
Corresponding Author:

\section{VU Raut}

Horticulture Section, College of

Agriculture, Amravati Road,

Nagpur, Maharashtra, India

\section{Effect of planting dates and $\mathrm{GA}_{3}$ on growth, flowering and yield of golden rod}

\author{
VU Raut, Pooja Baghele, Neha Chopde and Seema Thakre
}

DOI: https://doi.org/10.22271/chemi.2020.v8.i1w.8491

\begin{abstract}
An experiment entitled "Effect of planting dates and $\mathrm{GA}_{3}$ on growth, flowering and yield of golden rod" was carried out during Kharif season of the year 2018-2019 at Satpuda Botanical Garden, Horticulture Section, College of Agriculture, Nagpur, Dr. PDKV, Akola (M.S.). The treatments comprised of four planting dates viz., $15^{\text {th }}$ June, $15^{\text {th }} \mathrm{July}, 15^{\text {th }}$ August and $15^{\text {th }}$ September and three levels of $\mathrm{GA}_{3}$ viz. Control, $200 \mathrm{ppm} \mathrm{GA} 3$ and $250 \mathrm{ppm} \mathrm{GA}$. Before planting suckers of golden rod were dipped in $\mathrm{GA}_{3}$ solution of different concentrations as per the treatment for 6 hours. The experiment was laid out in Factorial Randomized Block Design with three replications. The results revealed that, in respect of growth parameters, plant height with panicle, number of leaves plant ${ }^{-1}$ and plant spread were recorded significantly maximum with the planting date of $15^{\text {th }}$ June and suckers treatment with 200 ppm GA 3 . In respect of flowering parameters, initiation of panicle and opening of first flower were registered significantly earliest when golden rod suckers planted on $15^{\text {th }}$ June and treated with $200 \mathrm{ppm} \mathrm{GA}$. The yield parameters like number of panicles plant ${ }^{-1}$ and ha ${ }^{-1}$ were also found significantly maximum with the planting date of $15^{\text {th }}$ June and the sucker's treatment with 200 ppm GA3.
\end{abstract}

Keywords: Golden rod, planting date, $\mathrm{GA}_{3}$, growth, flowering, yield

\section{Introduction}

Solidago commonly known as "Golden rod" belongs to the family Asteraceae. Golden rod (Solidago canadensis L.) is a perennial flowering plant which is grown for its attractive, long and straight flower stalk. It is commonly grown in beds, borders, rock gardens and also for cut flower in India. Because of its easy cultivation, adaptability to varying soil and climatic conditions and excellent keeping quality, there is a great scope for cultivation of golden rod in India. It is generally used as cut flower for indoor decoration as well as in bouquets making as a filler along with other flowers. It has a very good potential for dry flower industry.

This crop did not receive a much attention of researchers in the past under Vidharbha conditions and therefore, technological information for these areas is much scanty. Gibberellic acid plays a vital role in improvement of vegetative growth characters of the plant as it enhances the cell elongation and cell division by promoting the DNA synthesis in the cell. It reduces the juvenile phase due to an increase in photo-synthesis and respiration with enhanced carbon-di-oxide fixation in the plant. Keeping in view the potentialities of gibberellic acid, the present study was undertaken to find out the suitable planting time and concentration of $\mathrm{GA}_{3}$ for the better growth, flowering and yield of golden rod.

\section{Materials and Methods}

Present experiment was carried out at Satpuda Botanical Garden, Horticulture Section, College of Agriculture, Nagpur during 2018-2019. The treatment comprised of the four planting dates viz., $15^{\text {th }}$ June, $15^{\text {th }}$ July, $15^{\text {th }}$ August and $15^{\text {th }}$ September and three $\mathrm{GA}_{3}$ concentrations viz.

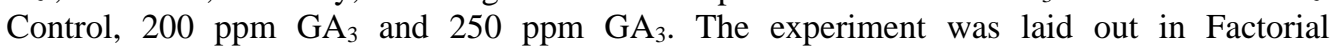
Randamised Block Design (FRBD) and replicated thrice. Golden rod suckers were dipped with three levels of gibberellic acid (0, 200 and 250 ppm GA 3 ) solution for 6 hours. Planting of GA 3 soaked golden rod suckers was done as per different dates of planting. Farmyard manure was applied @ 600 $/ \mathrm{m}^{2}$ to all the plots uniformly and incorporated in to the soil, whereas, the fertilizers were applied @ 150:100:100 kg/ha N, $\mathrm{P}_{2} \mathrm{O}_{5}$ and $\mathrm{K}_{2} \mathrm{O}$, respectively. Irrigation was applied thrice in a week for one month and twice in week afterwards. Hand weeding was 
carried out as and when required. Five plants were selected randomly from each plot for recording various growth parameters viz. plant height with panicle, number of leaves plant $^{-1}$ and plant spread, flowering parameters viz., days to initiation of panicle and days to opening of first flower and yield parameters like number of panicles plant ${ }^{-1}$ and hectare ${ }^{-1}$. Various observations were recorded at proper stages and the data was statistically analysed by the method suggested by Panse and Sukhatme (1995) ${ }^{[8] .}$

\section{Results and Discussion}

The data presented in Table 1 revealed that, different dates of planting and levels of $\mathrm{GA}_{3}$ had significant effect on growth, flowering and yield parameters of golden rod.

Table 1: Effect of planting dates and $\mathrm{GA}_{3}$ concentrations on growth, flowering and yield of golden rod

\begin{tabular}{|c|c|c|c|c|c|c|c|}
\hline Treatments & $\begin{array}{l}\text { Plant height } \\
\text { with panicle } \\
\text { (cm) }\end{array}$ & $\begin{array}{c}\text { Number of } \\
\text { leaves plant }{ }^{-1}\end{array}$ & $\begin{array}{c}\text { Plant spread } \\
(\mathrm{cm})\end{array}$ & $\begin{array}{c}\text { Days to initiation of } \\
\text { panicle (days) }\end{array}$ & $\begin{array}{l}\text { Days to opening of } \\
\text { first flower (days) }\end{array}$ & $\begin{array}{c}\text { Yield of } \\
\text { panicles plant }^{-1}\end{array}$ & $\begin{array}{c}\begin{array}{c}\text { Yield of panicles } \\
\text { hectare } \\
\text { (Lakh) }\end{array} \\
\end{array}$ \\
\hline \multicolumn{8}{|l|}{$\begin{array}{l}\text { A. Planting dates } \\
\text { (D) }\end{array}$} \\
\hline $\mathrm{D}_{1}-15^{\text {th }}$ June & 71.03 & 35.14 & 26.11 & 35.01 & 78.70 & 4.84 & 3.59 \\
\hline $\mathrm{D}_{2}-15^{\text {th }}$ July & 66.09 & 33.16 & 24.66 & 38.37 & 78.90 & 4.25 & 3.14 \\
\hline $\mathrm{D}_{3}-15^{\text {th }}$ August & 63.53 & 32.98 & 22.53 & 41.13 & 84.02 & 4.05 & 3.00 \\
\hline $\mathrm{D}_{4}-15^{\text {th }}$ September & 65.96 & 33.13 & 23.18 & 40.46 & 82.93 & 4.17 & 3.02 \\
\hline F test & Sig. & Sig. & Sig. & Sig. & Sig. & Sig. & Sig. \\
\hline $\mathrm{SE}(\mathrm{m}) \pm$ & 1.11 & 0.56 & 0.43 & 1.27 & 1.35 & 0.09 & 0.06 \\
\hline $\mathrm{CD}$ at $5 \%$ & 3.26 & 1.66 & 1.27 & 3.73 & 3.96 & 0.26 & 0.18 \\
\hline \multicolumn{8}{|l|}{$\begin{array}{c}\text { B. GA3 } \\
\text { Concentrations (G) }\end{array}$} \\
\hline $\mathrm{G}_{0}-0 \mathrm{ppm} \mathrm{GA}_{3}$ & 64.74 & 32.18 & 22.30 & 41.84 & 83.52 & 4.17 & 3.08 \\
\hline $\mathrm{G}_{1}-200$ ppm GA 3 & 68.38 & 35.29 & 25.48 & 35.15 & 78.25 & 4.47 & 3.31 \\
\hline $\mathrm{G}_{2}-250 \mathrm{ppm} \mathrm{GA} 3$ & 66.83 & 33.33 & 24.58 & 39.24 & 81.64 & 4.34 & 3.18 \\
\hline F test & Sig. & Sig. & Sig. & Sig. & Sig. & Sig. & Sig. \\
\hline $\mathrm{SE}(\mathrm{m}) \pm$ & 0.96 & 0.49 & 0.37 & 1.10 & 1.17 & 0.07 & 0.05 \\
\hline CD at $5 \%$ & 2.82 & 1.44 & 1.10 & 3.23 & 3.43 & 0.21 & 0.15 \\
\hline \multicolumn{8}{|l|}{$\begin{array}{l}\text { C. Interaction (D x } \\
\text { G) }\end{array}$} \\
\hline F test & N.S & N.S & Sig & N.S & N.S & N.S & N.S \\
\hline $\mathrm{SE}(\mathrm{m}) \pm$ & 2.35 & 1.20 & 0.91 & 2.69 & 2.86 & 0.19 & 0.13 \\
\hline CD at $5 \%$ & - & - & 2.69 & - & - & - & - \\
\hline
\end{tabular}

Table 2: Interaction effect of planting dates and levels of $\mathrm{GA}_{3}$ on plant spread in golden rod

\begin{tabular}{|c|c|}
\hline Treatment combinations & Plant spread (cm) \\
\hline $\mathrm{D}_{1} \mathrm{G}_{0}$ (Planting date of $15^{\text {th }}$ June + no sucker treatment with $\mathrm{GA}_{3}$ i. e. control) & 23.70 \\
\hline $\mathrm{D}_{1} \mathrm{G}_{1}$ (Planting date of $15^{\text {th }}$ June + sucker treatment with $\left.\mathrm{GA}_{3} 200 \mathrm{ppm}\right)$ & 29.41 \\
\hline $\mathrm{D}_{1} \mathrm{G}_{2}$ (Planting date of $15^{\text {th }}$ June + sucker treatment with $\left.\mathrm{GA}_{3} 250 \mathrm{ppm}\right)$ & 25.23 \\
\hline $\mathrm{D}_{2} \mathrm{G}_{0}$ (Planting date of $15^{\text {th }} \mathrm{July}+$ no sucker treatment with $\mathrm{GA}_{3}$ i. e. control) & 22.86 \\
\hline $\mathrm{D}_{2} \mathrm{G}_{1}$ (Planting date of $15^{\text {th }}$ July + sucker treatment with $\left.\mathrm{GA}_{3} 200 \mathrm{ppm}\right)$ & 25.70 \\
\hline $\mathrm{D}_{2} \mathrm{G}_{2}$ (Planting date of $15^{\text {th }}$ July + sucker treatment with $\left.\mathrm{GA}_{3} 250 \mathrm{ppm}\right)$ & 25.43 \\
\hline $\mathrm{D}_{3} \mathrm{G}_{0}$ (Planting date of $15^{\text {th }}$ August + no sucker treatment with $\mathrm{GA}_{3}$ i. e. control) & 21.18 \\
\hline $\mathrm{D}_{3} \mathrm{G}_{1}$ (Planting date of $15^{\text {th }}$ August + sucker treatment with $\left.\mathrm{GA}_{3} 200 \mathrm{ppm}\right)$ & 23.32 \\
\hline $\mathrm{D}_{3} \mathrm{G}_{2}$ (Planting date of $15^{\text {th }}$ August + sucker treatment with $\left.\mathrm{GA}_{3} 250 \mathrm{ppm}\right)$ & 23.10 \\
\hline $\mathrm{D}_{4} \mathrm{G}_{0}$ (Planting date of $15^{\text {th }}$ Sept. + no sucker treatment with $\mathrm{GA}_{3}$ i. e. control) & 21.48 \\
\hline $\mathrm{D}_{4} \mathrm{G}_{1}$ (Planting date of $15^{\text {th }}$ Sept. + sucker treatment with $\left.\mathrm{GA}_{3} 200 \mathrm{ppm}\right)$ & 23.50 \\
\hline $\mathrm{D}_{4} \mathrm{G}_{2}$ (Planting date of $15^{\text {th }}$ Sept. + sucker treatment with $\left.\mathrm{GA}_{3} 250 \mathrm{ppm}\right)$ & 24.56 \\
\hline F test & Sig. \\
\hline $\mathrm{SE}(\mathrm{m}) \pm$ & 0.91 \\
\hline $\mathrm{CD}$ at $5 \%$ & 2.69 \\
\hline
\end{tabular}

\section{Growth parameters}

\section{Effect of planting dates}

Significantly maximum plant height with panicle $(71.03 \mathrm{~cm})$, number of leaves plant ${ }^{-1}(35.14)$ and plant spread $(26.11 \mathrm{~cm})$ were recorded when the golden rod suckers planted on $15^{\text {th }}$ June and it was followed by planting date of $15^{\text {th }}$ July (66.09 $\mathrm{cm}, 33.16$ and $24.66 \mathrm{~cm}$, respectively), whereas, minimum values were recorded with the planting date of $15^{\text {th }}$ August $(63.53 \mathrm{~cm}, 32.98$ and $22.53 \mathrm{~cm}$, respectively).

From the above results, it has been noticed that, planting date of $15^{\text {th }}$ June was superior than other planting dates in respect of growth parameters. An increase in vegetative growth parameters due to early planting might be due to the favourable climatic conditions during earlier month's i.e. juvenile phase of the plants which stimulates cytokinin and gibberellins accumulation, modifying the hormonal balance and leading the growth parameters. These results are in close conformity with the findings of Dilta et al. (2006) ${ }^{[3]}$ in carnation and Pakhale et al. (2012) ${ }^{[7]}$ in African marigold.

\section{Effect of $\mathrm{GA}_{3}$ concentrations}

The plant height with panicle $(68.38 \mathrm{~cm})$, number of leaves plant $^{-1}(35.29)$ and plant spread $(25.48 \mathrm{~cm})$ were observed significantly highest when the golden rod suckers treated with 
200 ppm $\mathrm{GA}_{3}$ which was statistically at par with $250 \mathrm{ppm}$ $\mathrm{GA}_{3}(66.83 \mathrm{~cm}, 24.58 \mathrm{~cm}$ and 33.33, respectively). However, minimum plant height with panicle $(64.74 \mathrm{~cm})$, number of leaves plant $^{-1}(32.18)$ and plant spread $(22.30 \mathrm{~cm})$ were reported in control treatment. The increase in growth parameters with GA3 treatment over control might be because of the fact that $\mathrm{GA}_{3}$ promotes vegetative growth by inducing active cell division and cell elongation, which might have resulted in increasing the growth parameters. These findings are also supported by Bharathi et al. (2009) ${ }^{[1]}$ in tuberose, Nandre et al. (2009) ${ }^{[5]}$ in China aster and Osman and Seweden (2014) ${ }^{[6]}$ in golden rod.

\section{Interaction effect}

The interaction effect of planting dates and levels of $\mathrm{GA}_{3}$ on growth parameters viz. plant height with panicle and number of leaves plant ${ }^{-1}$ in golden rod was found statistically nonsignificant. However, in respect of plant spread the interaction effect was found significant.

The treatment combination of $\mathrm{D}_{1} \mathrm{G}_{1}$ (planting on $15^{\text {th }}$ June with $200 \mathrm{ppm} \mathrm{GA}_{3}$ ) significantly recorded maximum plant spread $(29.41 \mathrm{~cm})$ which was followed by $\mathrm{D}_{2} \mathrm{G}_{1}$ (planting on $15^{\text {th }}$ July with $200 \mathrm{ppm} \mathrm{GA}_{3}$ ) i.e. $25.70 \mathrm{~cm}$. However, minimum plant spread $(21.18 \mathrm{~cm})$ was observed in the treatment combination of $\mathrm{D}_{3} \mathrm{G}_{0}$ (planting on $15^{\text {th }}$ August with no treatment of $\mathrm{GA}_{3}$ i.e. control). An increase in plant spread of golden rod might have been due to the combine effect of planting date i. e. 15 June and suckers treatment with gibberellic acid 200 ppm.

\section{Flowering parameters \\ Effect of planting dates}

Days required for initiation of panicle and opening of first flower were recorded significantly minimum with the planting date of $15^{\text {th }}$ June (35.01 and 78.70 days, respectively) which was found statistically at par with $15^{\text {th }}$ July (38.37 and 78.90 days, respectively). However, maximum days taken for initiation of panicle (41.13 days) and days to opening of first flower (84.02 days) was noted with the planting date of $15^{\text {th }}$ August. The flowering was delayed with $15^{\text {th }}$ August planting which might have been due to non-availability of required temperature and day length for initiation of panicle and opening of first flower in golden rod due to which the juvenile phase of the plant might have been extended.

\section{Effect of GA3 concentration}

Significantly minimum days were required for initiation of panicle (35.15 days) and opening of first flower (78.25 days) when the suckers of golden rod treated with 200 ppm $\mathrm{GA}_{3}$ which was followed by 250 ppm $\mathrm{GA}_{3}$ (39.24 and 81.64 days, respectively), whereas, significantly late initiation of panicle (41.84 days) and opening of first flower (83.52 days) were reported with the control treatment. The minimum days to opening of first flower by $\mathrm{GA}_{3}$ might be due to the fact that, $\mathrm{GA}_{3}$ is quite effective in reducing the juvenile period of plants. More or less similar results are reported by Bharathi et al. (2009) ${ }^{[1]}$ in tuberose, Dalal et al. (2009) ${ }^{[2]}$ in gerbera and Dogra et al. $(2012)^{[4]}$ in gladiolus.

\section{Interaction effect}

The interaction effect of planting dates and levels of $\mathrm{GA}_{3}$ on flowering parameter viz. days to initiation of panicle and days to opening of first flower in golden rod was found statistically non-significant.

\section{Yield parameters}

\section{Effect of planting dates}

Significantly maximum number of panicles plant ${ }^{-1}$ (4.84) and $\mathrm{ha}^{-1}$ (3.59 lakh) were harvested with the planting date of $15^{\text {th }}$ June which was followed by $15^{\text {th }}$ July (4.25 and 3.14 lakh). However, minimum number of panicles plant ${ }^{-1}$ (4.05) and ha ${ }^{-1}$ (3.00 lakh) were noted with $15^{\text {th }}$ August planting date. The plants planted on $15^{\text {th }}$ June produced good vegetative growth, thereby proper development of required photosynthetic system which helps to increase the production of flowers which in turn resulted in increased number of panicles plant ${ }^{-1}$ and $\mathrm{ha}^{-1}$. Similar results have also been reported by Sreekanth et al. (2006) ${ }^{[10]}$ and Pakhale et al. (2012) [7] in African marigold.

\section{Effect of $\mathrm{GA}_{3}$ concentrations}

The number of panicles plant ${ }^{-1}$ (4.47) and hectare a $^{-1}$ (3.31 lakh) was registered significantly maximum when the golden rod suckers treated with $200 \mathrm{ppm} \mathrm{GA}_{3}$ and it was found statistically at par with 250 ppm $\mathrm{GA}_{3}$ (4.34 and 3.18 lakh). Whereas, minimum number of panicles plant ${ }^{-1}(4.17)$ and ha- ${ }^{1}$ (3.07 lakh) were reported in the control treatment. This increase in number of panicles per plant and per hectare due to $\mathrm{GA}_{3}$ application over control might be due to increased vegetative growth in respect of plant height and spread and number of leaves, which is essential for production of carbohydrates in the plants. These carbohydrates are translocated towards the reproductive parts of the plants for production of of flowers. These results are in conformity with the findings of Nandre et al. (2009) ${ }^{[5]}$ in China aster and Rajput et al. (2011) ${ }^{[9]}$ in golden rod.

\section{Interaction effect}

The interaction effect due to the date of planting and $\mathrm{GA}_{3}$ levels on the yield of panicles plant ${ }^{-1}$ and ha ${ }^{-1}$ was found nonsignificant.

Thus, it can be inferred from the present investigation that, maximum growth and flower yield with earliest flowering was recorded in golden rod when the suckers planted on $15^{\text {th }}$ June and treated with $200 \mathrm{ppm} \mathrm{GA}_{3}$.

\section{References}

1. Barathi TU, Kumar S. Effect of growth regulators on growth and flowering parameters of tuberose cv. Suvasini. Adv. Plant Sci. 2009; 22(1):127-128.

2. Dalal SR, Somavanshi AV, Karale GD. Effect of gibberellic acid on growth, flowering, yield and quality of gerbera. Int. J Agri. Sci. 2009; 5(1):355-356.

3. Dilta BS, Badiyala SD, Sharma YD, Verma VK. Effect of planting dates and pinching methods on growth and flower production in carnation. Int. J Agri. Sci. 2006; (2):216-218.

4. Dogra S, Pandey RK, Bhat DJ. Influence of gibberellic acid and plant geometry on growth, flowering and corm production in gladiolus (Gladiolus grandiflorus). Int. J Pharm. Bio. Sci. 2012; 3(4):1083-1090.

5. Nandre DR, Navandar UO, Watane AD. Effect of growth regulators on growth, flowering and yield of China aster. The Asian J Hort. 2009; 4(1):50-51.

6. Osman AR, Sewedan E. Effect of planting density and gibberellic acid on quantitative and qualitative characteristics of Solidago canadensis "Tara" in Egypt. Asian J Crop Sci. 2014; 6:89-100.

7. Pakhale S, Golliwar VJ, Panchbhai DM, Jibhakate P, Deshmane S. Response of African marigold varieties to 
different planting times on growth and yield under Vidarbha conditions. J Soil and Crops. 2012; 22(1):183187.

8. Panse VG, Sukhatme PV. Statistical Methods for Agricultural Workers. New Delhi, Publication and Information Division, ICAR, 1995.

9. Rajput SG, Borse PS, Patel HC. Effect of growth substances on flowering, yield and quality of flower stalks of golden rod. Int. J Agric. Sci. 2011; 7(1):209211.

10. Sreekanth P, Padma M, Chandrasekhar R, Madhulety TY. Effect of planting time, spacing and nitrogen levels on yield and quality of African marigold (Tagetes erecta L.) J Orna. Hort. 2006; 9(2):97-101. 